\title{
The Impact Of Covenant University Micro Finance Bank On Small Businesses In OTA And ENVIRONS
}

\author{
I. Chiazor
}

\section{A. Jegede}

\section{I. Ozoya}

\section{Adebayo}

\begin{abstract}
This study assessed the impact made by Covenant Microfinance Bank (CMFB) on Small Scale Businesses in Ota and its environs since inception. The immediate objective of this research was to examine how CMFB have impacted the lives of Small Scale Businesses through the Micro-credit loans it gives to these categories of persons who are generally regarded as the poor in Ota community and its environs. Survey method was employed in this study. Copies of questionnaire were administered to respondents systematically selected from the list of CMFB loan beneficiaries. They consist of petty traders, farmers, artisan, okada riders (Commercial Bike Riders), hair dressers and suppliers. The loans given out by CMFB served as take-off capital that is generally regarded as a crucial tool in alleviating poverty among the poor segment of every community. Findings from this study show that majority of the respondents have been empowered and lifted from poverty, as they were able to utilize the microcredit they obtained from the Bank in expanding their businesses. Thus establishing the fact that micro-financing is a powerful tool for poverty alleviation. It is the view of the researchers that further studies be undertaken to assess CMFB impact on other categories of the bank's customers not covered by this study.
\end{abstract}

Key Word: CMFB Ota, MFIs' Impact, Small Businesses, Microcredit, Poverty Alleviation

\section{INTRODUCTION}

Since its inception, observers have speculated about the potential of microfinance to lift individuals and households out of poverty. Microfinance is the provision of financial services such as loans, savings, insurance, and training to people living in poverty. It is one of the great success stories in the developing world in the last 30 years and is widely recognized as a just and sustainable solution in alleviating global poverty. Microfinance involves the provision of small-scale financial services to economically active but poor people. The clients are typically self-employed, low-income entrepreneurs. They are often traders, street vendors, small farmers, service providers (hairdressers and drivers), artisans, and small producers [1].

Throughout the world, poor people are excluded from the formal financial system. Exclusion ranges from partial exclusion in developed countries to full exclusion in less developed countries (LCD). Owing to their inability to access formal financial services, the poor have developed a wide variety of informal community based financial arrangements to meet their financial needs. [2]. The unwillingness or inability of the formal financial institutions to provide financial services to the urban and rural poor, coupled with the unsustainability of government sponsored development financial schemes, contributed to the growth of private sector led 
Microfinance programs that are geared to filling this gap in Nigeria as in other parts of the developing world [3].

Microfinance programs and institutions have become an increasingly important component of strategies designed to reduce poverty and promote micro and small enterprise development [4]. The issues of poverty reduction and the plight of the poorest in society have witnessed unprecedented attention at international Summits since the 1990s [5]. The general assumption is that if one gives more microfinance to poor people, poverty will be reduced. So, many see microfinance as an effective and powerful tool for poverty reduction. But like many other development tools however, it has insufficiently penetrated the poorer strata of society. However, knowledge about the achievement of the microfinance initiatives remain only partial and contested [4]. At one extreme are writers who hold the view that microfinance is of immense benefit to society. At the other end are those who caution against such optimism. In the middle are works that identify beneficial impacts but argues that micro finance does not assist the poorest, as is so often claimed [6].

[7] found in their studies consistently that a country with higher MFIs' gross loan portfolio per capita tends to have lower levels of poverty indices, which corroborates the poverty reducing role of microfinance. Further -more econometric results consistently confirm that microfinance loans per capita are significantly and negatively associated with poverty, which means that a country with a higher MFIs' gross loan portfolio per capita tends to have lower poverty after controlling for the effects of other factors influencing it. Given the state of affairs among the poor in the developing world, especially in Sub- Saharan Africa (SSA), the assessment of microfinance programs designed to alleviate their poverty, remain an important field for researchers, policy makers and development practitioners. It is in the light of the foregoing that this study is undertaken with a view to assessing the impact made on Small Businesses in Ota and environs by Covenant Microfinance Bank (CMFB) since its inception. Has the Bank through its microcredit schemes been able to lift their customers who belong to the lower rung of Ota Community, out of their poverty? This and many other questions this study sought to address.

\section{PROFILE OF THE COVENANT MICROFINANCE BANK LIMITED}

Covenant Microfinance Bank Ltd (CMFB) birthed as a financial support institution in line with the mental productivity initiative of the Covenant University Vision. It commenced banking business on $15^{\text {th }}$ March, 2004, as Covenant University Community Bank Ltd. It transformed into Microfinance Bank in 2009, having met the Central Bank of Nigeria policy requirements on conversion. The main office of the Bank is located in the heart of Canaan Land, Ota, Ogun state, Nigeria, with a cash point on the University Campus. The main goal of CMFB is to help men and women take their place in the wealth creation wave of this information age. The bank act as a catalyst in enabling members of Ota community and environs achieve accelerated economic growth and development. In its drive at impacting the community where it is situated, CMFB have developed products and services especially for poor people in order to enhance their income generation capacity. The principal mission of CMFB is to help meet the developmental needs of Ota community, promote creativity and service as instrument of wealth creation.

CMFB, being passionate about transforming ordinary individuals into creators of wealth, have extended micro credits to a large number of their poor customers in Ota and environs, with a view to lifting them up from poverty. CMFB other products and services include traditional accounts similar to those run by commercial banks and specialized ones designed to meet the specific needs of their customers. These include Covenant Gold Account, Covenant Silver Account, Covenant Children Savings Scheme and Shiloh Savings Scheme. CMFB to further drive 
its vision of serving as an instrument of wealth creation positioned itself strategically to meet the development needs of small and medium scale businesses. To achieve this goal, it designed Microcredit Scheme for small businesses, trade groups and artisans such as welders, tailors, vulcanizers and okada (Motor- Bike riders).

\section{OBJECTIVE OF THE STUDY}

The main objective of this study was to assess the extent to which CMFB have helped to reduce poverty among the poor in Ota and environs and how far it has helped to improve the socioeconomic status of their customers who belong to the class of Small Business Owners in Ota and environs were selected for the study because CMFB is located in Ota and this represents the immediate community it serves.

The specific objectives were to:

1. Determine how effective CMFB Micro Credits have been in reducing poverty among the small business owners and the poor in Ota and environs.

2. Determine the extent to which Micro Credits have impacted on the status of the beneficiaries

3. Determine how CMFB Credits to the poor has helped in alleviating their poverty.

4. Determine the extent to which CMFB Microcredit to the poor have impacted on their living conditions.

5. Derive policy implications from the study that could be useful in the design of future Microcredit services targeted at the poor in Ota and environs and even the world at large.

\section{LITERATURE REVIEW AND THEORETICAL FRAMEWORK}

There are numerous references in this area of study. A number of scholars have done studies on the role that Micro financing play in small scale businesses. In view of this therefore, care was taken to select relevant literature and theories to support this study. Funding for Microfinance Programs generally derives from regular loan savings of participant members, the interest paid on loans, or outside sources like non-governmental organizations, the IMF or World Bank and other international donors [1]. Microcredit is the extension of very small loans (Micro-Loans) to impoverished borrowers who typically lack collateral, steady employment and a veritable credit history. It is designed not only to support entrepreneurship and to alleviate poverty, but also in many cases to empower women and uplift entire communities by extension. It helps expand opportunity for people living in poverty.

The Microcredit movement had its origin in Asia in the 1970s and since then, much has been written about its thinking, practices and impacts there. In contrast, there is relatively little known about Microfinance in Sub-Saharan Africa (SSA) to where the Micro-credit movement spread in the 1980s and where it became stronger in the 1990s (Alkire and Santos, 2010). SSA is the poorest region in the world, according to the Multidimensional Poverty Index Developed by Oxford University and featured in the UNDP's 2010, Human Development Report. Since Microfinance is geared at serving the poor, SSA is therefore an important region to consider when reviewing the impact of Microcredit on the poor. Ota and its environs, the focus of this study, falls within this region and so it is expedient that a study of this nature be undertaken to assess the impact of Covenant Microfinance Bank Micro Credit Scheme on small businesses in the locality where it is situated. According to Yunus Muhammad "Microcredit views each person as a potential entrepreneur and turns on the tiny economic engine of a rejected portion of society" (CGAP 2010). 
Fehmeen (2010), in his work, quoted Bono as putting an interesting twist to an old adage; "Give a man a fish and he'll eat for a day. Give a woman Microcredit, her husband, her children and her extended family will eat for a life time." The simple quote above sum up the power of credit to develop entire societies in a bottom- up manner instead of just the top-down manner traditionally employed by the commercial sector. The question to ask at this point is has CMFB Microcredits to small business owners in Ota and environs had the same impact as asserted by Bono above? Findings from this study will help to answer this question. The Grameen Bank in Bangladesh is known world -wide for its success in providing credit to the poor. Has CMFB Microcredit Scheme been able to replicate Grameen Bank order of success in Ota and environs? Findings from this study will show the direction of CMFB's impact.

Past studies have shown that the poor want to save, can save and do save, but when it comes to the challenge of turning their small savings into large working capital, they need the infrastructure and discipline of microfinance since it is among the only method of saving that do not require assets. It is well known that commercial banks are not interested in lending to the poorer sectors due to their mind set that loan to the poor are too small, too risky, and too costly to administer [1]. Similarly, rural people have limited or no access to formal credits and other financial services, just like the poor in virtually every society in SSA. In response to this situation, there have been increasingly active informal financial markets that have been eager to fill the gap left by commercial banks, which are unable or unwilling to serve the rural population and the poor in general. Other players in the Micro credit world such as International Projects and programs, as well as NGOs, are also trying to get a share of this market.

The United Nations in giving recognition to the crucial role Microcredit play in poverty alleviation or reduction, declared 2005 "year of Microcredit". This marked the long journey of Microcredit from an obscure experiment in the mid-1970s to the status of a World Wide Movement [11]. No wonder it is generally claimed today that the greatest discovery of the Grameen-Led Microfinance movement has been the credit worthiness of the poor.

\section{MICROFINANCE IN NIGERIA}

Microfinance is found all over the world in places such as Africa, Latin America and Asia. Informal microfinance systems predated the formal microfinance sector in Nigeria and have remained in existence. There are several forms of informal finance in Nigeria including the Moneylender or Pawnbroker who are individuals that extend credit, usually with excessively high interest rates. Therefore, empirical studies of this nature (Impact Assessment of CMFB), need to be undertaken to provide more evidence on the impact of microfinance on the poor. As asserted by [12] in her work, the extent to which the CMFB, like other Nigerian Microfinance banks (MFBS) microcredit programs have benefited Small Businesses in Ota and environs is worthy of investigation and forms the thrust of this study.

These results explain the role of microfinance in poverty alleviation in Nigeria and corroborate the findings of [13] which indicated that the use of microfinance to fight poverty (i.e. welldesigned microfinance schemes) can improve the lots of the poor and can lift them out of poverty. Now, there is clear evidence that the provision of credit to the very poor households and businesses raises their standard of living [2016].

\section{THEORETICAL FRAMEWORK}

The study adopted the Needs theory in explaining poverty. Needs theory views humans as people who are in need in one form or the other. It presents the existence of certain universal needs that must be satisfied if people are to lead a good life. According to Abraham Maslow's 
[15] conception of human development, as the sequential satisfaction of basic needs, there are five categories of human needs. These are physiological, safety, belongingness/love, esteem, and self-actualization. [16] further expatiated on these needs to become eight. He referred to them as eight fundamental needs whose satisfaction was a pre-requisite to preventing deviant behaviors among individuals in society. They include the primary needs for consistency of response, stimulation, security, and recognition, and derivative needs for justice, meaning, rationality and control. One salient need among the views of the forgoing scholars is that of basic need, which is termed as psychological by Maslow and primary by Sites. This level of needs is what is dominant among the poor in the Nigerian context.

The application of this theory is that if Microfinance banks, which are set up to alleviate poverty among the poor through credit provision, perform their functions adequately, then the basics can be elevated from the level of basic needs to meeting higher needs and ultimately, attain self- actualization. It is assumed that the poor in Ota and environs would be lifted out of poverty and be able to meet their basic needs if the micro credits given to them by the CMFB are well utilized. It is this issue of the impact of CMFB on the lives of small business owners in Ota that this study sought to interrogate.

\section{METHODOLOGY}

This study was aimed at assessing the impact of Covenant Microfinance Bank (CMFB) on small Businesses in Ota and environs. The study was designed and conducted using the quantitative and qualitative methodology. This involved the use of structured questionnaire containing both open and close ended- questions and in-depth interviews were also conducted. Well trained interviewers were used to administer the questionnaires. The respondents were selected from CMFB list of Small Business owners who have benefitted from CMFB Microcredit Loans over time. The method is ideal because the study involved collecting data from customers of CMFB with a view to determining whether or not Microfinance contributed to poverty reduction in their lives by increasing their income and welfare.

\section{Sampling Technique}

Systematic random sampling was used to select from the list of beneficiaries, customers to be interviewed on issues pertaining to the impact CMFB micro-credits had on these individuals and their families.

\section{Data Collection}

The methods adopted for data collection in this study included the use of questionnaire and face to face interview with some beneficiaries of CMFB Microcredit packages. They were studied in-depth so as to understand in details how much CMFB had impacted their lives and businesses since they became CMFB Customers. The researcher used a structured checklist for discussion with this category of beneficiaries. The beneficiaries were able to tell their stories on how they rose from nothing to where they were now. They said this was largely due to their wise use of the loans obtained from CMFB. 180 CMFB Microcredit beneficiaries were selected for the purpose of this study. A total of 160 of the respondents returned their questionnaire .The data collected which were essentially descriptive in nature, were coded, and processed into percentages and frequency tables.

\section{RESULTS AND DISCUSSIONS}

The aim of this research was to empirically assess the impact of CMFB on Small Scale Businesses in Ota and environs. We will now discuss our research findings in relation to the variables tested as contained in the tables below. 
TABLE 1: Demographic data of respondents

\begin{tabular}{|l|l|l|l|l|l|l|}
\hline Variable & Frequency & Percentage & Variable & Frequency & Percentage \\
\hline Age & & & & Religion & & \\
\hline $18-23$ & 14 & 8.75 & & Christians & 134 & 83.75 \\
\hline $24-29$ & 24 & 15 & & Muslims & 26 & 16.25 \\
\hline $30-35$ & 32 & 20 & & Total & 160 & 100 \\
\hline $36-41$ & 26 & 16.25 & & Marital Status & & \\
\hline $42-47$ & 24 & 15 & Single & 40 & 25 \\
\hline $48-53$ & 16 & 10 & Married & 114 & 71.25 \\
\hline $54-59$ & 8 & 5 & Divorced & 2 & 1.25 \\
\hline $60-65$ & 16 & 10 & Widowed & 4 & 2.5 \\
\hline Total & 160 & 100 & & Total & 160 & 100 \\
\hline Sex & & & No of Children & & \\
\hline Male & 50 & 68.75 & & One & 18 & 11.25 \\
\hline Female & 110 & 31.25 & Two & 64 & 40 \\
\hline Total & 160 & 100 & & More than 2 & 78 & 48.75 \\
\hline Education & & & Total & 160 & 100 \\
\hline $\begin{array}{l}\text { No formal } \\
\text { education }\end{array}$ & 8 & 5.0 & & & & \\
\hline Primary & 92 & 57.50 & Farming & 12 & 7.5 \\
\hline Secondary & 55 & 34 & & Trading & 72 & 45 \\
\hline Tertiary & 5 & 3.12 & Artisan & 32 & 20 \\
\hline Total & 160 & 100 & & Other & 44 & 27.5 \\
\hline & & & Total & 160 & 100 \\
\hline
\end{tabular}

Source : Data from the Field.

A sample size of 160 beneficiaries of the CMFB Micro-credit schemes was selected for this analysis. 134 of these respondents (83.75 \%), were between ages 18 and 52 years . 110 of them, representing (68.75\%) were females and (31. 25\%) were males. Data shows that 95\% of the respondents had formal education and $5 \%$ had no formal education. Majority of the beneficiaries were Christians (83\%), while 71\% of them were married,25\% single and others were divorced or widowed. $11 \%$ had 1 child , $40 \%$ had 2 children and $48 \%$ had more than two. Majority of the respondents were engaged in trading activities (45\%), others were either artisans or farmers (see table 1 above). 
TABLE 2: Impact of CMFB on its customers

\begin{tabular}{|c|c|c|c|c|c|}
\hline Variable & Frequency & Percentage & Variable & $\begin{array}{l}\text { Frequ } \\
\text { ency }\end{array}$ & Percentage \\
\hline Banked with CMFB & & & $\begin{array}{l}\text { Previous } \\
\text { monthly income }\end{array}$ & & \\
\hline Yes & 100 & 100 & No income at all & 16 & 10 \\
\hline No & 0 & 0 & Less than 10000 & 32 & 20 \\
\hline Total & 160 & 100 & Less than 20000 & 54 & 33.75 \\
\hline $\begin{array}{l}\text { Benefited from } \\
\text { CMFB }\end{array}$ & & & 20000 and above & 58 & 36.25 \\
\hline Yes & 160 & 100 & Total & 160 & 100 \\
\hline No & 0 & 0 & Monthly income & & \\
\hline Total & 160 & 100 & $20000-29000$ & 24 & 15 \\
\hline How CMFB helped & & & $30000-39000$ & 32 & 20 \\
\hline Easy access to credit & 60 & 37.5 & $40000-49000$ & 30 & 18.75 \\
\hline Training skills & 18 & 11.25 & 50000 and above & 74 & 46.25 \\
\hline $\begin{array}{l}\text { Income generating } \\
\text { projects }\end{array}$ & 46 & 28.75 & Total & 160 & 100 \\
\hline From grass to grace & 36 & 22.5 & Type of Service & & \\
\hline \multirow[t]{4}{*}{ Total } & 160 & 100 & Micro credit & 80 & 50 \\
\hline & & & $\begin{array}{l}\text { Equipment } \\
\text { leasing }\end{array}$ & 36 & 22.5 \\
\hline & & & Other & 44 & 27.5 \\
\hline & & & Total & 160 & 100 \\
\hline
\end{tabular}

\section{Source : Data from the Field}

Table 2 shows that majority of the respondents who bank with CMFB (75\%), and had enjoyed micro-credit from the bank, do not regard themselves as poor. This is due largely to the fact that their financial status has changed, their monthly income has increased and have been lifted from the claws of poverty. Their standard of living has improved. The easy access they have to CMFB microcredit schemes which includes training, income generating projects have impacted their lives positively. Theirs is a case of being lifted from "grass to grace". Businesses of respondents were boosted by increasing their working capital, expand their businesses and improved their saving culture. The respondents suggested a number of areas that the CMFB should improve upon in their operation and they include the following: Bank officers should spend less time in processing micro-credit applications; Increase the amount the Bank gives to their Customers as microcredit; Reduce customers waiting time in the banking hall; and the bank should embark on sensitization drives from time to time so as to enlarge her customer base.

\section{CONCLUSION AND RECOMMENDATIONS}

This study set out to examine the impact CMFB has made on small scale businesses in Ota and Environs since its inception. The method employed for this study included a questionnaire based survey of CMFB Customers who are small business owners, with a view to determining changes, if any in their living conditions and other variables at the individual, enterprise and household levels. One hundred and eighty copies of questionnaire were given out and one 
hundred and sixty were found useable for data analysis. Qualitative enquiry, using in-depth interviews were also carried out to complement the data generated from the questionnaire distributed. This study used Poverty theory and Needs theory to analyze the effects that Microfinance has on poverty reduction.

The ultimate goal of a Microfinance Institution is to offer services similar to those of a regular bank, and be committed to delivering a range of products and services that serve the poor. Going by the responses of the respondents for this study, the CMFB seem to have performed well in this direction, as it has succeeded in lifting small business owners and their poor customers who are beneficiaries of the Bank's microcredit schemes from poverty. There are many stories of the transformative effect of Microfinance on individual borrowers, but until recently there has been surprisingly little rigorous research that attempts to isolate the impact of Microfinance from other factors, or to identify how different approaches to Microfinance change outcomes [17]. It is with a view to filling this gap especially on the Nigerian scene, that this study was undertaken. The Covenant Microfinance Bank impact on the lives of their poor customers, who belong to the lower rung of the economic and social ladder of Ota and environs were measured, using a number of variables as indicated under the data analysis (see tables under Results and Discussion).

Results from in-depth interview of some of the CMFB small Business owners in Ota and environs shows that the impact of credit enjoyed by them go beyond income and employment as some of them have been able to build their own houses and even built for some of their employees. A typical example is madam $\mathrm{x}$ who now runs a chain of Restaurants in Ota. Others include Mr. Y, who make Ice-cream and Yogurt and now has a number of employees. Also, worthy of note are the popular poultry owners. These are persons who like many others were extremely poor in the past, but CMFB has so impacted their lives that today they have become a reference point in Ota Community.

Households of many beneficiaries of CMFB Micro-Credits have been transformed and their living standard improved, such that they can now pay school fees for their children, even up to tertiary levels and have built houses for themselves. Financial services to poor people have no doubt, proven to be a powerful instrument for reducing poverty, as it has enabled them to build assets, increase incomes and reduce their vulnerability to economic stress [9]. This corroborates the assertion of [18] that microfinance is a viable tool for closing the widening inequality in the developing world. CMFB Microcredit schemes are now being seen as unique programs that have brought about the reduction of poverty vulnerability among small business owners in Ota and environs. Majority (85\%) of the beneficiaries interviewed for this study said the Bank has empowered them and has lifted them out of poverty. This finding corroborates [7] that revealed that Microfinance significantly reduces poverty at macro level and thus reinforce the case for channeling funds from development finance institutions and governments of developing countries into microfinance institutions.

This is also in line with the assertion made by [19] "With each loan, a woman living in extreme poverty is empowered to build a business. With each business, a woman not only lifts herself out of poverty, she creates jobs and transforms lives in her community. Together, these entrepreneurs help communities around the world achieve prosperity" [19]. There is a significant effect Microfinance Institutions have on poverty alleviation by increasing income and changing economic status of those who patronize them. They are indeed a potent strategy for poverty reduction and a viable tool for purveying credit to the poor. However, Microfinance can become a more viable tool for sustainable poverty alleviation if more is done on program outreach and depth than the present outreach [3]. 
It is hoped that lessons learned from this impact assessment would be incorporated in future impact assessment of the remaining categories of CMFB Customers not covered by this study. A number of respondents said that the loan repayment period was too short. We therefore recommend that the schedule should be extended. Since the ultimate goal of a Microfinance Institution should involve being able to deliver a range of products and services that serve the poor, and the poor have already proven their need and their potential to succeed, all they just need is convenient product delivery systems. We therefore recommend that the interest rates charged the poor borrowers by CMFB should be very low and should not at any point be a par with what is generally charged by formal commercial banks. We also recommend that MFI's strive to simplify the application process for loan applicants; they should institute a proper saving mechanism for participants and diversify the types of products available to participants. MFI's should also innovate the traditional approach to lending by integrating training and educational programs into services offered to participants and create an atmosphere of trust and transparency between the participants and the MFI agents. This will help garner more savings from participants thereby increasing the availability of capital resources for borrowers.

The poor in Ota and environment, especially the small business owners should be encouraged to form cooperatives. This way , they would be able to attract bigger loans for their businesses and faster too since the cooperatives would serve as collateral that Banks always insist on before extending the much-needed loans to the poor. This will help lay to rest the vexatious issues of lack of acceptable Collateral that has prevented large number of small business owners and the poor from assessing CMFB's Microcredit loans. The cooperative would serve as pressure group on members to ensure that loans collected by them are well utilized and not diverted. The government should provide a healthy environment for financial services for the poor and ensure a stable Macro-economic and financial management, institute helpful rather than restrictive legislations governing promoters and providers of financial services for the poor. If applied properly, these actions will greatly contribute to the flourishing and sustainability of Microfinance in Nigeria as a whole.

\section{References:}

Boko Sylvain, Rosita Nagimi., Mina Baliamoune,Lutz and Skimuna. (2005) Women in Africa Development, the Challenges of globalizatison and liberalization in the $21^{\text {st }}$ century. Edited by Sylvain, H.Boko, et al. Africa World Press, INC, Trenton, NJ - 08607.

Irobi, N. C (2008) Microfinance and Poverty Alleviation: A case study of Obazu progressive women Association, Mbieri, Imo state, Department of Economics. Uppsala.

Jegede C, A, Kehinde, James Akinlabi, Babatunde Hamed. (2011). Impact of microfinance on poverty Alleviation I Nigeria: An empirical Investigation. European Journal of Humanities and social sciences: ISSN -2220-9425, Vol 2 , No. I ( 2011)

Hulme, D. (2000) - Impact Assesment Methodologies for Microfinance Theory, experience and better practice. World Development. 28(1) 79-88

Yunnus, M. (1999). Poverty Alleviation, Is Economic Any Help? Lessons from the Grameen Bank ExperienceJournal of International Affairs, 52, 47- 65, ISSN: 2220 -9425 - 110

Hulme \& Mosley, (1996) Finance Against Poverty, First Edition, Vol 1, London Routledge

Kastshushi, S. I., Raghav, G., Ganesh, T., \& Samuel, K. A. (2012). Microfinance and Poverty - A Macro Perspective . Uk World development, VOL 40, No 8, pp, 1675 - 1689, 2012 Elsevier Ltd.

Alkire and Santos: Multidimensional Poverty index 2010 data. Oxford poverty and Human development initiative. Available at www.ophl.org, featured inUNDP 2010 UK/Multidimensional poverty index.

CGAP (2010). Consultative Group to Assist the Poor. 
Fehmeen, (2010) Defining Microfinance, Entrepreneur, Insurance, loan, Microcredit, Microfinance Institution, Microfinance Trends.

DICWer (2006), The Microfinance Act 2006, No. 19 , Kenya Law

Oladejo, M (2013) Evaluation of the Nigeria Microcredit Banks Credit Admin on Small and Medium scale Enterprises Operations

Hulme and Paul (1996).

Lawanson, O. (2016) Asian Journal of Economic modeling. Alleviation Poverty through Microfinance. Nigeria's Experience- 2016, 4(3); 153-161, www.aessweb.com

Abraham Maslow (1954): Motivation and Personality reading. Addison Wesley Publishing Company.

Sites, P. (1973): Control: The basis of social Order. Associated Faculty Press, New York.

Chowburry, A. (2009): Microfinance as a Poverty reduction tool, a critical Assessment. Center for Global Development (2009)

Chiazor, I. \& Egharevba, M. ( 2016 ) Widening Inequality and Poverty in the Developing World. The Social Sciences. Medwell Journals, 2016. 3286. 3293

Opportunity International (2016): opportunity.org, Opportunity International Public foundation Newsweek 01-102016 